\title{
ERRATUM
}

\section{Acute postoperative neurological deterioration associated with surgery for ruptured intracranial aneurysm: incidence, predictors, and outcomes}

TO THE READERSHIP: An error appeared in the article by Mahaney et al. (Mahaney KB, Todd MM, Bayman $\mathrm{EO}$, et al: Acute postoperative neurological deterioration associated with surgery for ruptured intracranial aneurysm: incidence, predictors, and outcomes. J Neurosurg 116:1267-1278, 2012).

Although the IHAST Investigators were mentioned in the author byline, the members of this group who contributed to the study were not named. An Appendix has been added to the article to list these collaborators.

The article has been corrected online as of February 7, 2020.

Michael M. Todd, MD

University of Minnesota, Minneapolis, MN

INCLUDE WHEN CITING

Published online February 7, 2020; DOI: 10.3171/2020.1.JNS111277a.

CAANS 2020, except where prohibited by US copyright law 